\title{
Activity-Based Costing System Required For Successful Customer Relationship Management
}

Tiffany Bordovsky, (E-mail: tbordovsky@hotmail.com), Texas A\&M University-Kingsville Neal R. VanZante, (E-mail: N-Vanzante@tamuk.edu), Texas A\&M University-Kingsville George R. Wagman, (E-mail: DocWagman@sbcglobal.net), Texas A\&M University-Kingsville

\begin{abstract}
The purpose of this paper is to discuss the importance of Activity-Based Costing to successful Customer Relationship Management. The value a customer adds to a company through customer loyalty, using Customer Profitability Analysis.
\end{abstract}

\section{SUCCESSFUL CUSTOMER RELATIONSHIP MANAGEMENT}

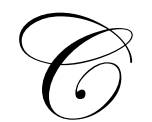

ustomer relationship management (CRM) is a set of business strategies and aligned business processes aimed at profitably anticipating, understanding, and responding to the needs of an enterprise's current and potential customers" (Inforte, 2002). An important component of CRM is the ability to measure customer-profitability. Customer-profitability is the value a customer adds to a company through customer loyalty, growth, promotion, and insight. Using customer-profitability analysis (CPA), "managers can ensure that customers making large contributions to the operating income of a company receive a level of attention from the company matching their contribution to the company's profitability" (Horngren, 2003). The success of CPA depends on the accuracy of the data used to analyze customer profitability. The refined cost data provided by Activity-Based Costing (ABC) systems allows for more accurate determination of customer-profitability. The purpose of this paper is to discuss the importance of $\mathrm{ABC}$ to successful CRM.

\section{CUSTOMER RELATIONSHIP MANAGEMENT}

CRM has been with us for several years, but there have been few unqualified successes and skeptical rumblings about the whole concept are getting louder. A report by analysts at Butler Group, CRM: Pitfalls \& Potential, says that CRM technology "has a long way to go before it even begins to live up to industry hype", and that 70 percent of CRM implementations fail (McKenzie, 2001).

According to Inforte (2002), "CRM presents a seductive and compelling message to executives in search of answers to customer-related challenges. The perception of CRM to the market has been a technological 'miracle drug,' promising to cure the ills surrounding customer relationships and the operational aspects of sales, marketing, and after-sales service." Unfortunately, the lofty expectations associated with CRM have not been met. "CRM has not shown itself to be the 'miracle cure' for solving all problems related to customer interactions. In fact, most organizations have been consistently disappointed with results from their CRM investments. A study of management tools by Bain \& Company showed that CRM ranked near the bottom in terms of satisfaction. Twenty percent of companies reported that their CRM initiatives had not only failed to deliver profitable growth but had also actually damaged customer relationships" (Inforte, 2002).

According to Meltzer (2004), CRM "demands that you understand which customers create profits and those that destroy it. There is a fixation by many companies on being product driven whilst paying lip service to being customer centric and espousing all the CRM words yet they remain product-aligned organizations." "Customercentricity is an important concept in the CRM umbrella, and building a customer-focused organization is necessary 
to creating profitable customer relationships" (Inforte, 2002). As quoted by McKenzie (2002), Tom Richards of Meridian Research "defines CRM as the means to target the 'right type' of customers, to convince them to buy profitable products and to retain them throughout the lifetime of their profitability." Thus, successful CRM systems depend on the ability to accurately measure customer profitability.

\section{CUSTOMER PROFITABILITY ANALYSIS}

CPA involves the identification of revenues and costs by individual customer or customer group. Although there is widespread acceptance of the concept of CPA, "in most companies, there is very little information available about the profitability of customers, with management accounting systems designed primarily to analyze product profitability (Coad, 1990). Connolly and Ashworth (1994) state that product profitability information is not good enough because the cost caused by making a product is strongly bound to the long-term investments. The impact of altering product mix on costs might be much less than expected because certain resources have been acquired for manufacturing certain products and might not be applicable for some others. The resources for serving the customers can be more easily utilized with different customers (Seppanen and Lyly-Yrjanainen, 2002).

By combining both revenue and cost data, CPA provides management with the vital information regarding their customer base, which is essential if well-informed decisions are to be made in the long term. CPA should enable management to answer key questions such as:

- Do our target markets meet our profitability criteria? Have they ever? Can they ever? If so, how?

- Which accounts generate the greatest profit contribution and how can we best protect them?

- What are the maximum discount/service packages we can afford in the next round of negotiations with our operators while still meeting our own profit objectives?

- $\quad$ Do our large corporate accounts really make money? Under what conditions are we prepared to walk away from that volume and what will we have to do as a consequence?

- $\quad$ Should we stay in this market? (Noone and Griffin, 1997)

According to McKenzie (2002), "if the desired outcome of CRM is (more) profitable customers, it presupposes that we can measure customer profitability, which, in turn, means accurately measuring customer revenue and all attributable customer costs incurred throughout the organization. What is more, this must be done at the customer segment and individual customer level. Typically, "accounting systems do not take into account the potential profits and losses attached to individual customers, customer segments, or the ranges of products" (Meltzer, 2004). There is a growing recognition among practitioners of CRM that it is time to dust off ABC and take a fresh look at how it can provide the necessary information. To measure customer profitability for the purposes of CRM, Tom Richards (of Meridian Research) strongly recommends ABC (McKenzie, 2001).

\section{ACTIVITY-BASED COSTING}

$\mathrm{ABC}$ has been recognized as a suitable tool for calculating customer costs. With the differences between the set of activities performed for each customer known, the true customer costs can be calculated (Seppanen and Lyly-Yrjanainen, 2002). The fundamental difference between the traditional method of costing and ABC is the way indirect costs are assigned to products and services (Noone and Peter, 1997). While ABC was initially applied to product profitability analysis, its scope has extended with $\mathrm{ABC}$ techniques being used by companies in CPA systems (Connolly and Ashworth, 1994). This approach views the customer rather than the product as the cost object for relevant customer-driven activities. "This type of information derived from $\mathrm{ABC}$ analysis provides management with a clearer insight into the actual profitability of their customer groups and provides a sound basis for customer mix decisions both in the short and long term"(Noone and Peter, 1997).

Horngren (2003) identifies $\mathrm{ABC}$ as "one of the best tools for refining a costing system." ABC refines a costing system by focusing on individual activities as the fundamental cost objects. An activity is an event, task, or unit of work with a specified purpose. To apply ABC to customers, a customer cost hierarchy categorizes costs related to customers into different cost pools on the basis of different types of cost drivers, or allocation bases, or 
different degrees of difficulty in determining cause-and-effect or benefits-received relationships. Customer cost categories might include:

- $\quad$ customer output unit-level costs (cost of activities to sell a unit to a customer, such as product handling costs);

- $\quad$ customer batch-level costs (costs of activities related to a group of units, such as costs incurred to process orders or to make deliveries);

- $\quad$ customer-sustaining costs (cost of activities to support individual customers, regardless of the number of units or batches, such as costs of visiting customers or costs of displays at customer locations);

- distribution-channel costs (costs of activities related to a particular distribution channel rather than to each unit, batch, or specific customer, such as salary of the manager of a retail distribution channel);

- $\quad$ corporate sustaining costs (costs of activities that cannot be traced to individual customers or distribution channels, such as top management and general administration costs) (Horngren, 2003).

McKenzie (2001) states that "ABC takes the hit and miss out of the costing process. The method is simple:

- $\quad$ identify resources in the company that have a cost or financial value-people, assets, etc.;

- $\quad$ identify activities in the company;

- determine how each type of resource is consumed by an activity and allocate the cost of these resources to each of the identified activities using a rational consumption method;

- $\quad$ identify the factor that drives each activity;

- determine the volume of each driver associated with each customer, product, service or channel of distribution;

- $\quad$ allocate cost to customers and products on the basis of driver volumes.

\section{CONCLUDING REMARKS}

The premise of this paper is that $\mathrm{ABC}$ is necessary for successful CPA, which in turn is necessary for successful CRM. The success of CPA is dependent on the selection of an appropriate method of matching costs with customers and customer groups. In their article, Noone and Griffin (1997) concluded that ABC is the most effective and accurate costing method to apply to CPA in a hotel environment. Inforte (2002) concluded that "armed with customer profitability information and knowledge of how to use it, companies will be able to make better decisions surrounding customer acquisition and retention."

Krupnicki and Tyson (1997) said "the mechanics of an ABC are straightforward, but a company intending to conduct an $\mathrm{ABC}$ study must be prepared to devote sufficient resources to it. People involved in the project must spend a great deal of time looking at what really drives costs in their business by observing activities, interviewing employees, and performing quantitative methods such as regression analysis. A company that doesn't commit the necessary resources is bound to be disappointed with the results." On the other hand, $\mathrm{ABC}$ alone is not the answer to successful CRM. A cultural shift is necessary at both the management and employee level to focus on customer needs and to pool organizational resources and information across functional barriers. However, "insights gained from $\mathrm{ABC}$ should be a wake-up call to management and could help to prevent the CRM failure forecasts from becoming a reality" (McKenzie, 2001).

\section{REFERENCES}

1. Coad, A.F. "Into the nineties with strategic management accounting: Part five: Market-led accounting", ACCA Student's Newsletter; June, 1999, pp. 16-18.

2. Connolly, T. and Ashworth, G., "Managing customers for profit", Management Accounting, April, 1994, pp. 34-39.

3. Horngren, C.T., Datar, Srikant, M., and Foster, G. Cost Accounting: A Managerial Emphasis. Pearson Education, Inc.; 2003, pp. 383-386, 490-496. 
4. Inforte. "Customer profitability: Fulfilling the promise of CRM", Inforte Corporation. http://www.inforte.com/knowledge/points_of_view/content/pov_CRMproducts.pdf. 2002.

5. Krupnicki, M. and T. Tyson. "Using $\mathrm{ABC}$ to determine the cost of servicing customers", Management Accounting, December, 1997, pp. 40-46.

6. McKenzie. "Serving suggestions", Financial Management, December, 2002, pp. 26-27.

7. Meltzer, M. "A CRM approach to customer profitability”, CRM Today. www.crm2day.com. 2004.

8. Noone, B. and Griffin, P. "Enhancing yield management with customer profitability analysis", International Journal of Contemporary Hospitality Management, September, 1997, pp. 75-59.

9. Seppanen, M. and Lyly-Yrjanainen. "Vague boundaries of product and customer costs", 2002 AACE International Transactions, EBSCO Publishing, 2002, pp. RISK12.1-12.6.

\section{NOTES}

